\title{
The Roles and Capabilities of Formal, Non-Formal, and Informal Institutions in Shaping Education Access in Cigugur Sub-district, West Java, Indonesia
}

\author{
Michelle Lim ${ }^{1}$, Lucky Permana ${ }^{2}$, Vinsensius Billy Hongo ${ }^{3}$, Kanaya Kiandra ${ }^{4}$, Kathryn \\ Nabasa $^{5}$, Albert Hasudungan ${ }^{6}$ \\ 1,2,3,4,5,6 Universitas Prasetiya Mulya, Indonesia \\ albert.hasudungan@pmbs.ac.id
}

\begin{abstract}
The objective of this research paper is to explore the capacities of formal, non-formal, and informal educational institutions, as parts of social institutions. The roles of these institutions will be assessed within the urban, middle, and rural areas of Cigugur sub-district in Kuningan. This research uses qualitative methods, comprising interview and 1-month participant observation in the field. From this research, it was found that the education access in the urban areas of Cigugur boasts an abundance of formal education, in which the skills that were shaped are literacy and communication skills. On the other hand, the middle - areas, which lack formal education, rely on non-formal institutions (such as the local churches and local Islamic organizations (pesantren) to shape ethical and entrepreneurship education through a series of communal meetings. In fact, due to the rare availability of formal education in the rural areas, knowledge spillover from older to younger generations is delivered through informal conversations to shape basic entrepreneurial skills in their informal businesses. The academic contribution of this article is to illuminate the different roles and capabilities of social institutions to deliver different access to education in their various geographical contexts.
\end{abstract}

Keywords

institutions, qualitative methods education access, geographical contexts, entrepreneurship education

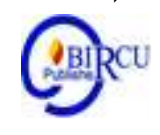

\section{Introduction}

In various economic development literature, education plays an important role to enhance human capital in order to achieve their well-being (Hart, 2018; Teixeira \& Queirós, 2016). While education is valuable to enhance human capital, a very limited number of studies exist that assess the performance of the respective social institutions to support the access of education delivered in the variety of local geographical contexts. This study aims to extend the existing understandings by assessing the roles of different social institutions in their specific geographical contexts. The goal of this study is to assess the roles of formal, non-formal, and informal institutions to shape the access of education in Cigugur sub-district, Kuningan.

Kuningan itself possesses unique geographical characteristics. According to the Government of Kuningan Regency, Kuningan Regency or Kabupaten Kuningan, lies in the West Java province of Indonesia (Pemerintah Daerah Kuningan, n.d.). The regency itself consists of 32 sub-districts which are then divided into 361 villages and 15 wards.

In this field of research, the authors will focus on one specific sub-district, which is the Cigugur sub-district, where the writers were stationed in 5 different villages. These villages 
consist of: Winduherang village, Cigugur village, Cisantana village, Mulya Asih village, and Cileuleuy village.

They are then categorized further into 3 characteristic categories; labelled as the urban, middle, and rural areas, in order to facilitate further explanations regarding the classifications of the villages. An urban area will be described as an area which is the nearest to the local government and economy center. It is also demographically denser and equipped with wellbuilt infrastructure. A middle-urban area is an area between urban and rural areas. It is an area which is able to enjoy some benefits of an urban area but is still lacking in some areas such as infrastructure access.

On the other hand, a rural area is one that is lacking in a lot of aspects according to the researchers' interview with some community respondents and field observation. These lacking aspects include easy access to education, equal quality of facilities, positive economic condition, and a high teacher quality. The rural area is also hindered in terms of their distance from the local government and economic center. The citizens in this area strongly maintain their cultural traditions, and their occupations mainly consist of being farmers and the like since they are usually located near fields and other natural resources. In this context, Winduherang and Cigugur villages are categorized as a part of an urban area, Cisantana village is a part of a middle-urban area, and Mulya Asih and Cileuleuy villages are a part of a rural area. The mapping of these areas can be seen in Figure 1.

In those field locations, The citizens inhabiting these areas all procure different income levels, derived from the differing economic livelihood activities which stem from the differences in their education backgrounds. Here, education plays an important role, as it provides an explanation regarding the different lifestyles and mindsets which can be observed in the villages. However, there are also several internal factors within the village that play a large role in influencing the education levels in different contextual areas (urban, middle, and rural areas). They are identified as formal, non-formal, and informal education institutions that may provide either formal education (education obtained in schools) or informal education (education obtained outside of schools: entrepreneurial skills, direct social skills, experiencebased skills, etc.).

In the analysis, the term 'formal education institutions' refers to the established, officially listed, and structured academic institutions whose purpose is to provide education and nurture students, such as primary, middle, and high schools as well as higher education institutions (Cameron \& Harrison, 2012). Non-formal institutions are also established and officially listed; however, their main purpose is not for formal education. Unlike formal institutions, they have bigger purposes such as religious or economic goals (Ibid.). They are, for example, churches and mosques whose objective is to act as a means to conduct and lead religious activities or village-owned enterprises (BUMDs) which mainly focus on developing the region's economic well-being. Lastly, there also exists informal institutions which are the complete opposite of the first two institutions, as they are not structured and are more personal towards the students. They are mostly present in the form of social relationships, such as their families, peers, and local communities (Cameron \& Harrison, 2012; North, 1990). 


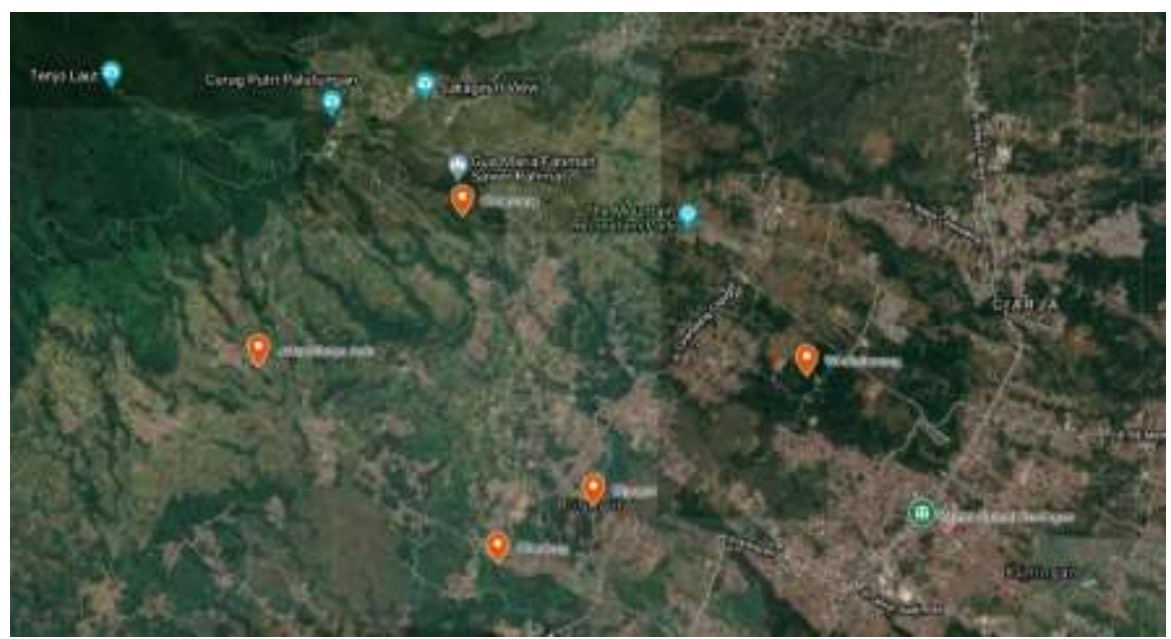

Figure 1. Research Area Mapping

Source: Google Maps

The specific research questions for this article are:

1. What are the inhibiting and supporting factors of the existing primary, junior, and senior high school formal education institutions in delivering education access?

2. What are the roles of formal, non-formal, and informal institutions to assist the society in obtaining formal and informal education access?

\section{Review of Literatures}

\section{Roles of Social Capital in Access to Education}

Sweetland (1996) stated that the prime form of human capital investment is none other than education as it is seen as a crucial factor in leveraging a nation's health, nutritional state, and eventually economic growth. Education itself exists varyingly; ranging from formal to informal education and even to vocational training. When these kinds of knowledge can function together properly as a network, it implies that the education delivery can be maximized. For example, a social network can increase the overall quality of life due to more people being able to contribute to the medical field, or people may master more skills necessary to enter the workforce which can substantially leverage their values in the labor market and help them to obtain higher wages. Thus, education can be linked to the enhancement of human capital, and ultimately these high-skilled humans together with a stronger social capital network can contribute more towards their own country's well-being.

Income is the amount received usually within a certain period of time is usually one year, community income is thus all receipts received in a particular year either from industry, trade and other sectors. The economic condition of the population is a condition that describes human life that has economic score. Economic conditions are assessed through three variables: livelihoods, income, and ownership of valuables. (Shah et al, 2020).

Economic growth is a long-term macroeconomic problem where in each period the people of a country will try to increase their ability to produce goods and services. The target is to increase the level of real production (national income) and standard of living (real income per capita) through the supply and mobilization of factors of production. With this increase it is expected to increase capital, production of each worker or in other words will increase foreign exchange reserves. (Magdalena and Suhatman, 2020)

In economic development literature, Sen (2007) underscored that limited education access is a source of economic deprivation, whereas the availability of education is a chance 
for low-income individuals to improve their unstable economic conditions. In fact, Sen (2007) emphasized that agents and institutions play a significant role in enhancing education access. In economic development, the influence of social institutions towards educational development can be traced back from the social capital theory. Social capital theory has largely evolved in the community development literature. The development of a community and economy is not only affected by the economic aspects such as described above, it is also affected by the social capital that exists. The social capital is heavily involved in the

development of the social structure of a community and the advancement of highly valued credentials and skills needed.

\section{Research Methods}

\subsection{Design (Voluntary Interview)}

The fieldwork study involved observing the phenomenon of educational deliveries through a one-month field visit in Cigugur sub-district, Kuningan, in February 2020. The researchers had previously requested permission from the various village heads to collect the data. Additionally, ethical issues of voluntary correspondence were negated by requesting permission from the available individuals to be included as respondents in this study. In detail, participant observations and in-depth interviews were utilized to collect the information. To prevent any misuse of the data collected, as well as to prevent any harm that could possibly be done, the identity of the participants is not publicized in this paper.

Direct observations were also conducted to minimize the influence of the researcher towards the environment and events that took place in the schools while taking into account many dimensions of any social situation (Spradley, 1980). In the local fieldwork, the researchers were not familiar with the social environment and did not have access to the respondents. Herewith, in speaking with the local community, joining with their daily activities, and gathering with some local community members, the researchers were familiarized with the existing environment and in particular could build rapport with the community. Besides, direct observation is conducted to observe attitudes of the participants in the learning process (Sihotang, 2019). Hence, this could become a mitigating factor to gain access to further information from the particular local community and students. However, these checkups were not able to be conducted equally for each observed school due to time constraints.

\subsection{Participants}

In this case study, the sampled educator participants were those educators that stayed and delivered education in the fieldwork locations. The participants of the data collection included teachers/educators, students, families, heads of schools, the government, and some community organizations (such as religious organizations, families, informal adolescent community organizations (Karang Taruna)) which in total the number of participants is 142 participants. Community organizations were selected by those who lived and were related to educational deliveries in the case sites, including those adolescent community organizations. The student respondents were the ones who experienced and lived through the pedagogical process. The government institutions were the local institutions that were directly related to the educational deliveries, such as the local education offices, the village head offices, and the sub-district offices. 
Table 1. List of Participants

\begin{tabular}{|c|c|c|c|}
\hline Subjects & Urban Area & Middle Area & Rural Area \\
\hline Teachers & 6 & 3 & 8 \\
\hline Students & 46 & 12 & 19 \\
\hline School Officials & 2 & 1 & 4 \\
\hline $\begin{array}{c}\text { Other Institution } \\
\text { Authorities }\end{array}$ & 2 & 2 & 4 \\
\hline Parents & 5 & 8 & 6 \\
\hline General Public & 8 & 3 & 1 \\
\hline
\end{tabular}

Source: Fieldwork in Kuningan, West Java

\subsection{Data Processing and Analysis}

In analyzing the roles of educational institutions in Cigugur, the study also utilized a SWOT analysis, which is an analytic tool that can be used to conduct strategic planning and management within an organization. This instrument is considered very effective to help an organization in building an appropriate strategy, both for internal and competitive strategies (Gürel, 2017). Alongside that, a coding analysis was devised to classify and organize the primary information from the informants that was relevant with these research questions.

\section{Result and Discussion}

This section attempts to answer the respective research questions that were previously stated in the introductory section.

\subsection{Supporting and Inhibiting Factors on Education Access}

The urban areas are located in Winduherang and Cigugur villages. The Winduherang and Cigugur villages are located near the local government office and economic center. Schools of all levels are available everywhere in the urban areas. The schools are Public Elementary School 1 Winduherang, Public Elementary School 2 Winduherang, Public Elementary School 2 Purwawinangun, Public Elementary School 5 Purwawinangun, Public Elementary School 1 Cigugur, Public Middle School 3 Cigugur, Vocational High School Muhammadiyah 1, and Public High School 1 Cigugur. The schools in the urban areas can be differentiated based on the funding schemes implemented, in which several schools are cross-funded by private sources. This creates a significant gap between those schools which are cross-funded and those which rely only on government funds. In this case, government-funded schools usually suffer from many delays to acquire further funding and consequently are unable to improve their infrastructure conditions. This is also apparent in terms of teachers' placement (NN1(Student), 2020). For schools that are labelled as favorites within the region, they experience a surplus in assigned teachers compared to other schools nearby.

However, some government funded schools do have sufficient infrastructure and teachers. According to the Principal of Public Elementary School 1 Cigugur, the school is able to obtain sufficient support from the local government due to its proactive approach in proposing various improvement programs for the school facilities. Consequently, Public Elementary School 1 Cigugur is one of the favorite primary schools in the region 
(NN2(Principle Cigugur Public Elementary School), 2020). In terms of the quality of the teachers, the government also provides periodic training for the teachers. There is also a regulation in Cigugur for schools to assign teachers based on their majors, and to only accept teachers that have an Education major. Those inhibiting and supporting factors can be seen further in the SWOT table below.

Table 2. SWOT Analysis of Education in Urban Areas

\begin{tabular}{|c|c|}
\hline $\begin{array}{l}\text { Strengths } \\
\text { - Many schools option. } \\
\text { Located near the government } \\
\text { office; easier access to } \\
\text { government support. }\end{array}$ & $\begin{array}{l}\text { Weaknesses } \\
\text { - Government-funded schools are } \\
\text { often neglected for support. } \\
\text { - Disparity of infrastructure } \\
\text { amongst several schools. }\end{array}$ \\
\hline $\begin{array}{ll}\text { Opportunities } \\
\text { - } \\
\text { - } \\
\text { - } \\
\quad \begin{array}{l}\text { High numberen awareness towards } \\
\text { education. }\end{array}\end{array}$ & $\begin{array}{l}\text { Threats } \\
\text { - The majority of the families are } \\
\text { lower-income families. } \\
\text { A lack of constant motivation } \\
\text { for students to keep studying. } \\
\text { A lack of high skill occupation } \\
\text { demands for higher education. }\end{array}$ \\
\hline
\end{tabular}

Source: Fieldwork in Kuningan, West Java

The middle area is located in Cisantana village. In this village, the major weakness in the area is the number of schools is very limited, with only 5 options for primary schools (4 public schools and 1 private school, Yos Sudarso Elementary School/ Kindergarten), 1 option for junior high school (Nurul Hidayah Cisantana Plus Middle School), and no options for the high school level (NN3(Village Head), 2000). This is worrying as it is therefore harder for Cisantana residents to acquire a decent education, especially those who strongly believe in Catholicism and wish to pursue their education in Catholic-based schools (which are usually private schools). Moreover, the number of students who are interested to go to private schools is not many; most of the lower income families prefer public schools which are lower in terms of quality as compared to the private ones, around $42.8 \%$ of the authors' total student respondents. Furthermore, since there are no high schools in the village, the nearest high school from the village is Public High School 1 Cigugur, which is not even located in Cisantana.

The quality of the facilities is also very unequal. The junior high school which is already standardized as a "plus" school has quite sufficient facilities, as even during the pandemic season, the schools can implement online learning. However, that is not the case for the public primary schools, as the facilities such as computer and science labs, proper desks, and quality of teachers are still lacking. In private schools such as Yos Sudarso Elementary School, aside from the teachers having motivation to teach, they also care deeply about the well-being of their students. One senior teacher even expressed his concerns regarding the students' unwillingness to give consistent effort in studying and hopes that it can be boosted through informal means such as the students' parents' contributions(NN 4(School teacher), 2020). Those supporting and inhibiting factors of middle area is summarized in Table 3 below.

Table 3. SWOT Analysis of Education in Middle Areas 


\begin{tabular}{|c|c|}
\hline \begin{tabular}{l}
\multicolumn{1}{c}{ Strengths } \\
- $\quad$ Provides timely training for \\
teachers. \\
Private school teachers are \\
responsible.
\end{tabular} & $\begin{array}{l}\text { Weaknesses } \\
\text { A limited number of schools in } \\
\text { primary and junior high schools } \\
\text { (5 schools in total). } \\
\text { - } \quad \text { No high schools are present. } \\
\text { A lack in quality and quantity } \\
\text { for facilities. } \\
\text { Accessibility is hard; students } \\
\text { need to go to other villages in } \\
\text { order to study. }\end{array}$ \\
\hline $\begin{array}{l}\text { Opportunities } \\
\text { - Students have ambitious dreams } \\
\text { and goals in life. } \\
\text { Parents are aware of the } \\
\text { importance of education. } \\
\text { Non-formal institutions (church } \\
\text { \& village-owned enterprises) } \\
\text { contribute to provide education. }\end{array}$ & $\begin{array}{l}\text { Threats } \\
\text { - Students migrate outside the } \\
\text { village to attain an education. } \\
\text { Most of the families are lower- } \\
\text { income families. } \\
\text { A lack of constant motivation } \\
\text { for students to keep studying. }\end{array}$ \\
\hline
\end{tabular}

Source: Fieldwork in Kuningan, West Java

Furthermore, in the rural areas of the region such as Mulya Asih and Cileuleuy villages, there are quite distinguishable differences as compared to the urban areas. In these areas, there are 6 elementary schools in total. For the middle school, however, there is only 1 school in the region of the survey. As for the high school, the closest high school to both villages are Public High School 1 Cigugur in Sukamulya village. This number shows that the rural areas in Cigugur are accommodated with enough primary education institutions. However, there are several shortcomings which include the lack of facilities and infrastructure. Regarding teacher quality, there are significant differences, as Cileuleuy village has teachers with higher competence compared to Mulya Asih village. The welfare of the teachers then can also be considered poor. One of the interviewees stated that teachers in the region of Cileuleuy have to work secondary jobs such as by farming and doing hard labor to support the needs of their families (NN5(School teacher), 2020).

Aside from that, the rural areas in Cigugur face several flaws, in which inaccessibility and inequality are two of the major factors that exist in the rural areas. Elementary schools in the regions of Cileuleuy and Mulya Asih villages are abundant. However, the lack of middle and high schools in these regions is a challenge for the students in the areas. In order to continue their high school education, the closest high school in the area is in the Sukamulya region, which takes around 10-15 minutes on motorcycle to reach the high school with bad road infrastructure. Thus, this can be a challenge for the students to increase their skills and capacity through education. Another challenge is the financial support where according to one of the interviewees, the funds needed to support the education such as clothing, etc. are quite hefty for their financial condition. The inhibiting and supporting factors are summarized in Table 4 below.

Table 5. SWOT Analysis of Education in Rural Areas 
Source: Fieldwork in Kuningan, West Java

\begin{tabular}{|c|c|}
\hline $\begin{array}{l}\text { Strengths } \\
\text { Teachers are provided training } \\
\text { regularly and are given } \\
\text { guidelines to teach. } \\
\text { Moral support to attain higher } \\
\text { education is high. }\end{array}$ & $\begin{array}{l}\text { Weaknesses } \\
\text { - A limited number of schools, especially } \\
\text { middle and high schools. } \\
\text { - The quality of the education is low. } \\
\text { - } \\
\text { Faccessibility is relatively hard. } \\
\text { supporting education attainment are } \\
\text { lacking/disproportionate. }\end{array}$ \\
\hline $\begin{array}{l}\text { Opportunities } \\
\text { Increased awareness towards } \\
\text { education. } \\
\text { Several students excel in their } \\
\text { academic and non-academic } \\
\text { education and look forward to } \\
\text { pursuing a higher level of } \\
\text { education. }\end{array}$ & $\begin{array}{l}\text { Threats } \\
\text { Most of the families are low-income } \\
\text { families. } \\
\text { The financial needs for education are } \\
\text { hefty. } \\
\text { Low demand of high-paying jobs that } \\
\text { requires a high level of education and } \\
\text { skills. } \\
\text { Discrimination still exists among the } \\
\text { teachers and students, as it is difficult for } \\
\text { minorities to achieve a greater target. }\end{array}$ \\
\hline
\end{tabular}

\subsection{Supporting and Inhibiting Factors on Education Access}

The presence of social institutions (formal, informal, and informal) plays a crucial role in shaping the educational access and delivery of each area. The way these bodies function are in line with the study conducted by Woolcock (2017) in such that these varying institutions exist hand-in-hand despite their own distinctive features and are able to form a social network that eventually shape the surrounding community. In greater detail, this section will dissect the prominence of each institution per area of study.

Formal institutions in the urban areas have been able to cater to most of the students because of the existence of free tuition schools that are funded by the government. Based on the observations, there are still some gaps in providing quality education due to the disparities in the infrastructure and teachers' placement amongst schools, which influence the limited enrollment of students.

Aside from this, non-formal institutions can be found through various religious institutions such as the local mosques or pesantren that provide religious education for the children in the areas. They play an active role in shaping the children's ethics and morals based on religion. Non-formal institutions are very significant for the development of the young generation, in which they act as a subsidiary education provider in making sure that each student receives not only structural academic education but also religious aspects to implant proper morals. This is gained through sekolah mengaji or sekolah Al-Quran. A local (NN6(villager), 2020) stated through one interview that although the era has advanced through globalization, the villagers can still maintain their morals and manners through religious studies. As stated:

"What is the use of being smart if you do not have morals or faith?" In this case, it can be seen that this Al-Quran school has an active role in shaping children's ethics, morals, and views of life based on religion." (NN6(villager), 2020)

Informal institutions such as nuclear families force the children to learn literacy and 
communication skills in order to allow them to work in formal sectors, yet they lack emphasis on developing an entrepreneurial spirit. For instance, in the urban areas in which there exist diverse formal labor opportunities, a parent in Winduherang village stated that through the availability of free tuition schools, their sons and daughters are more determined to shape their futures (NN7(Student's parent), 2020). Another piece of information gathered from a graduate of the Accounting major in UNIKU believes that through his parents' support and encouragement, he managed to graduate with a Bachelor's Degree. This has allowed him to gain many job opportunities and to start coordinating his own business with the hopes of decreasing unemployment in Cigugur.

From the conducted interviews, it is further proven that the citizens in the urban areas are more open-minded and are consistently looking forward to improving not only their own wellbeing but also their community as a direct result from the area being equipped with sufficient formal education. This is in line with the notion elaborated by Sweetland (1996) that education that is executed properly enhances the quality of human capital. Nevertheless, constrained by formal labor work, some parents and community members are preoccupied with their own business. Hence, the social networks to provide alternative informal education are weak in these location

Woolcock (2017) argue that modern and formal development interventions often overlooked the existing informal rules, norms and customs to provide some relevant local solutions. In this middle and rural areas, formal educations are constrained with the weak capacities to deliver even education access. Nonetheless, non-formal and informal institutions have provided provide some local solutions to transfer relevant knowledge to sustain local livelihoods.

On middle areas of this case study, education access is uneven and have been poorly delivered by the school teachers as well. Besides, as most working adults finished their education up until primary and junior high schools, their economic conditions are not very well off. The main occupations in the villages are as farmers and breeders with a few households owning their own businesses such as selling traditional beverages, foods, and cultural creations. Furthermore, the relatively wealthier families have higher education levels, such as an owner of a small business who finished her education in the third year of her university study or a popular salon owner who finished her education in high school (NN8(Student), 2020).

Due to the limited working opportunities in these middle areas, informal businesses such as trading agricultural products and other food and beverage items have been developed in order to support their economic livelihoods. With this informal business dependence, there has emerged unique ways of gaining formal and informal education access to improve entrepreneurial skills to support their informal businesses. Socially, the network that exists in Cisantana village is heavily based on gotong royong or kekeluargaan (collective help), as most businesses employ their own neighbors or family members with a value in mind that for any business in Cisantana village, it should aim to help the local people and economy.

In fact, it is also interesting to note that there are non-formal institutions that play a crucial role in strengthening societal values and they play a relatively more prominent role in society due to the formal institutions being relatively harder to access. To illustrate, the Catholic Church (Gereja Katolik Maria Putri Murni Sedjati) aims to empower local businesses and students by conducting classes for those who are disabled and helping to facilitate the businesses which might face difficulties in obtaining credit/funding(NN9(Enterpreneur), 2020). Village-owned enterprises (Badan Usaha Milik Desa) are also present to cultivate more local business opportunities, even though the scope is not only limited to Cisantana but to the whole Cigugur area. The enterprises focus on providing informal education such as entrepreneurial skills that are otherwise not obtained in schools. These non-formal 
organizations deliver informal training periodically (varied) according to the aspirations of their community members. For instance, at one time some community members wanted to develop a florist business. Hence, these non-formal organizations cooperated together with the community to deliver certain entrepreneurship skills to initiate the business. Therefore, despite the fact that schools in urban areas have not performed well, it is fortunate that the students are helped with the presence of non-formal and informal institutions. These institutions, despite the lack of formal education, thus can act as a prominent social network that can leverage the community's abilities. This arrangement is also supported by the theory proposed by Sen (2007) that the social capital, in this case the various institutions, is able to influence the development of community structure and advance the skills needed. For instance, from that training provided, the villagers will be able to hold further informal meetings later on to shape the entrepreneurship and other informal knowledge.

Furthermore, in rural areas, the availability of formal institutions can prove crucial assistance in the process of developing the younger generations. However, due to the lack of availability and access to sufficient formal institutions, the schools in rural areas like Cigugur village and Mulya Asih village fall short of their goals in aiding the education development of the students.

In addition, non-formal institutions have contributed (though limited) various religious pedagogies in a rural setting. For example, non-formal education, such as Islamic schools, plays a role in educating the Muslim children in the manners and ethics of Islam. This provides support for the development of the children's behavior to further assist with the formal and informal education received (NN10(Younger villager), 2020).

Nonetheless, the lack of formal education in the area led the informal institutions that are represented by parents' teachings to their children to be found in abundance in these rural areas. Due to the lack of financial capability, this form of education is the most common in the area. For instance, farming and agricultural information has been passed down from generation to generation and therefore preserves the farmers' work lineage. In addition, a communication network has been utilized by the villagers in order to conduct their daily purchases of necessities. The knowledge transfer from the older generation to the younger generation is often conducted through the word-of-mouth method, without any incurred training costs. This informal knowledge which can be regarded as the social network that exist in this area exchanged from the older to younger generations has helped some of the villagers to start their own, often small, informal businesses (NN11(Business owner), 2020). Similarly, in line with the theory of social capital by Sen (2007), the informal institutions as a social capital thus have the capabilities that allow the community to sharpen their skills despite its shortcomings through the copious efforts the parents have made to educate their children although the introduction of other education methods may help even more to positively increase the education in rural areas. The synthesis of the different social institutions to deliver education skills in the various areas is summarized in the table below.

Table 6. Main Strengths of Social Institutions to Deliver Education Areas Main Institutional Strength Education Delivered 


\begin{tabular}{|c|c|c|}
\hline Urban Areas & Formal education access & $\begin{array}{c}\text { Literacy and communication } \\
\text { skills }\end{array}$ \\
\hline Middle Areas & $\begin{array}{c}\text { Non-formal institutional } \\
\text { entrepreneurship training }\end{array}$ & $\begin{array}{c}\text { Entrepreneurship skills to } \\
\text { sustain informal business } \\
\text { enterprises }\end{array}$ \\
\hline Rural Areas & $\begin{array}{c}\text { Transferring some knowledge } \\
\text { from the older generation to the } \\
\text { younger generation }\end{array}$ & $\begin{array}{c}\text { Some agribusiness and trading } \\
\text { skills to sustain agribusiness } \\
\text { and informal business } \\
\text { enterprises }\end{array}$ \\
\hline
\end{tabular}

Source: Interviews and coding, 2020

\section{Conclusion}

The education system in Cigugur sub-district faces unequal access to formal education due to the impaired social network between the three areas that exist (urban, middle, and rural areas). These educational gaps within the sub-district can therefore result in uneven human capabilities to possess basic literacy and communication skills. It was also found that while the urban areas have enjoyed various benefits such as: diverse school access, adequate teachers, and diverse formal labor opportunities in the future for their young generation, these comfortable situations have to some extent discouraged some students to further strengthen their entrepreneurship skills. Additionally, these conditions have also been aggravated by some individualistic-minded and busy parents that in fact encourage their children to have formal careers rather than entrepreneurship ventures.

On the other hand, with the inadequate formal capabilities to deliver formal education in middle village areas, other non-formal institutions have provided some entrepreneurship training to communities in order to sustain their agribusiness and food beverage informal sectors. In the rural villages, the delivery of formal education is constrained with the lack of both physical and human infrastructure. In terms of physical infrastructure, the constraints consist of difficulty in transportation access and a lack of maintenance for the school buildings which then complicates matters for rural villagers when trying to achieve an adequate education quality.

Another problematic issue in the rural area, aside from the physical infrastructure, is the human capital itself. The human infrastructure in rural areas is determined to be rather lacking in their quantity and their capabilities in order to sufficiently transfer knowledge towards the students. physical and human infrastructure. Nevertheless, the informal knowledge transfer and trust amongst the older and younger villagers have managed to sustain the transfer of knowledge skills concerning the agribusiness and some trading skills among them, in which this valuable information is then used to survive despite their condition of impaired job opportunities and a lack of formal literacy education in the villages. Hence, the strong and resilient social networks of the non-formal and informal institutions found respectively in middle and rural areas are extremely crucial to create various alternative education access (e.g. entrepreneurship and religiosity) for the communities in those locations.

\section{Acknowledgement}


This work was supported by Pusat Pengembangan Usaha Kecil (PPUK) Universitas Prasetiya Mulya; and Department of Business Economics, School of Business and Economics, Universitas Prasetiya Mulya. We would like to say thank you for the support

\section{References}

Cameron, R., \& Harrison, J. (2012). The interrelatedness of formal, non-formal and informal learning: Evidence from labour market program participants. Australian Journal of Adult Learning, 52(2), 277-309.

Chiang, M. H. (2020). Exploring the effects of digital storytelling: A case study of adult L2 writers in Taiwan. IAFOR Journal of Education, 8(1), 65-82. https://doi.org/10.22492/ije.8.1.04

Dunn, K. (2005). Interviewing. In I. Hay (Ed.), Qualitative research methods in Human Geography, second edition (pp. 79-105). Oxford University Press. http://philpapers.org/rec/DUNI-4

Folland, S. (2007). Does "community social capital" contribute to population health? Social $\begin{array}{llll}\text { Science } & \& & \text { Medicine, } & \text { 64(11), }\end{array}$ https://doi.org/https://doi.org/10.1016/j.socscimed.2007.03.003

Gannon, B., \& Roberts, J. (2020). Social capital: exploring the theory and empirical divide. Empirical Economics, 58(3), 899-919. https://doi.org/10.1007/s00181-018-1556-y

Gürel, E. (2017). SWOT analysis: A theoritical review. Journal of International Social Research, 10, 994-1006. https://doi.org/10.17719/jisr.2017.1832

Hadi, K., Dazrullisa, Hasruddin, \& Manurung, B. (2019). The Effect of Teaching Materials Based on Local Value Integrated by Character Education through PBL Models on Students' High Order Thinking Skill. Britain International of Humanities and Social Sciences (BIoHS) Journal, 1(2), 213-223. https://doi.org/10.33258/biohs.v1i2.54

Hart, C. (2018). Education, inequality and social justice: A critical analysis applying the SenBourdieu Analytical Framework. Policy Futures in Education, 17(5), 582-598.

Hart, C., \& Brando, N. (2018). A capability approach to children' s well - being, agency and participatory rights in education. 53(3), 1-17. https://doi.org/10.1111/ejed.12284

Hasudungan, A., \& Neilson, J. (2020). Processes of land appropriation for large-scale oil palm development in West Kalimantan, Indonesia. Revista Nera, 23(51), 366-389. https://doi.org/https://doi.org/10.47946/rnera.v0i51.6542

Lee, Y., Rianti, I. P., \& Park, M. S. (2017). Measuring social capital in Indonesian community forest management. Forest Science and Technology, 13(3), 133-141. https://doi.org/10.1080/21580103.2017.1355335

NN 4(School teacher). (2020). Interview with fourth respondent (school teacher).

NN1(Student). (2020). Interview with first respondent (Student) cigugur.

NN10(Younger villager). (2020). Interviews with younger villager below 17 years old in Cigugur.

NN11(Business owner). (2020). interviews with agriculture business owners above 30 years old in Mulya Asih village.

NN2(Principle Cigugur Public Elementary School). (2020). Interview with second respondent (Principle of Cigugur Public Elementary School).

NN3(Village Head). (2000). Interview with third respondent (Village head in Cigugur).

NN5(School teacher). (2020). Interview with teacher in Cileuleuy.

NN6(villager). (2020). Interview with villager.

NN7(Student's parent). (2020). Interview with student's parent.

NN8(Student). (2020). Interview with student in urban area. 
NN9(Enterpreneur). (2020). Interviews with some informal business actors in Cisantana village.

Magdalena, S and Suhatman, R. (2020). The Effect of Government Expenditures, Domestic Invesment, Foreign Invesment to the Economic Growth of Primary Sector in Central Kalimantan. Budapest International Research and Critics Institute-Journal (BIRCIJournal). P. 1692-1703.

North, D. (1990). Institutions, institutional change, and economic performance. Cambridge University Press.

Pandapotan, S. (2019). Social Capital as a Local Wisdom of Farmer in Managing Agricultural Resources in Lubuk Pakam Sub-district, Deli Serdang District. Budapest International Research and Critics Institute (BIRCI-Journal) : Humanities and Social Sciences, 2(4), 469-476. https://doi.org/10.33258/birci.v2i4.603

Pemerintah Daerah Kuningan. (n.d.). Website Resmi Pemerintah Kabupaten Kuningan. Retrieved January 8, 2020, from https://www.kuningankab.go.id/

Sen, A. (2007). Children and Human Rights. Indian Journal of Human Development, 1(2), 235-245. https://doi.org/10.1177/0973703020070201

Sihotang, I. (2019). Learning Lesson Study in Improving Accounting Learning Results. Budapest International Research and Critics in Linguistics and Education (BirLE) Journal, 2(3), 529-537. https://doi.org/10.33258/birle.v2i3.424

Shah, M, et al. (2020). The Development Impact of PT. Medco E \& P Malaka on Economic Aspects in East Aceh Regency. Budapest International Research and Critics InstituteJournal (BIRCI-Journal). P. 276-286

Spradley, J. (1980). Participant observation. Holt, Rinehart and Winston.

Sweetland, S. (1996). Human Capital Theory: Foundations of a Field of Inquiry. Review of Educational Research - REV EDUC RES, 66, 341-359. https://doi.org/10.3102/00346543066003341

Teixeira, A., \& Queirós, A. (2016). Economic growth, human capital and structural change: A dynamic panel data analysis. Research Policy, 45(8), 1636-1648. https://doi.org/10.1016/j.respol.2016.04.006

Woolcock, M. (2017). Social Institutions and the Development Process: Using CrossDisciplinary Insights to Build an Alternative Aid Architecture. Polymath: An Interdisciplinary Arts and Sciences Journal, 7(2), 5-30. 